\title{
Desiring the past and reimagining the present: contemporary collecting in Qatar ${ }^{1}$
}

Karen Exell*

\begin{abstract}
The collecting processes in Qatar at state level is intimately linked with the construction of a new Qatari identity for global consumption and national cohesion. At an individual level, collecting can be linked with the desire to preserve the disappearing present in the face of rapid development, as well as representing local traditions of authority and erudition. The national collections created for the first Qatar National Museum institutionalize this process and re-classify the objects as representing the newly constructed 'Qatari' identity. The Msheireb Arts Center holds the Echo Memory collection of found objects, collected to inspire a Qatari future but representing the lives of the South Asian community otherwise excluded from the Qatari national discourse. Using these examples, this paper situates the processes of collection, curation and display within, or in opposition to, the ongoing process of Qatari national identity construction, preservation and dissemination, and presents them as a facet of Qatar's engagement with modernity and the reimagining of itself in the contemporary global age.
\end{abstract}

Key words: Qatar, collections, modernity, national identity, authorized heritage

\section{Introduction}

The tiny Gulf state of Qatar gained independence in 1971, and now reaps enormous wealth from its oil and gas reserves. It has emerged onto the global stage over the last decade, investing its hydrocarbon wealth in numerous commercial and cultural projects at home and abroad, with extensive international media coverage of its museum development and, in particular, its investment in contemporary western art. The Father Emir, Sheikh Hamad bin Khalifa Al Thani (1995-2013), instigated a programme of cultural development, including the building of museums such as the Museum of Islamic Art (opened 2008), Mathaf: Arab Museum of Contemporary Art (opened 2010), and the new National Museum of Qatar (due 2018), designed by western 'starchitects' such as I.M. Pei and Jean Nouvel. Recent exhibitions have included the headlining-grabbing Damien Hirst retrospective, Relics (10 October 201322 January 2014) at the Al-Riwaq exhibition hall, and the controversial exhibition by the Algerian artist, Adel Abdessemed, L'Age d'Or (6 October 2013-5 January 2014), at Mathaf. Qatar Museums' Public Art department has installed a number of artworks around the city, including Abdessemed's Coup de Tête statue, a five-metre high bronze statue of Zinedine Zidane head-butting Marco Materazzi in the 2006 World Cup. According to the Damien Hirst website (http://www.damienhirst.com/news/2014/relics-visitor-figures), visitor numbers reached 62,000 for the Relics exhibition, while observational and anecdotal evidence indicated that the majority of visitors were expatriates living in Doha, which could be said to be representative of the population demographic (see below); however, an undercurrent of disapproval for such non-locally relevant state investments rumbles in the local media and twittersphere (Exell 2016), and may have contributed to the unexplained removal of the Zidane statue from its original place of installation on Doha's corniche just weeks after its installation. These cultural developments were part of the outward-looking internationalization agenda of the Father Emir, Sheikh Hamad, who pursued a policy of political and cultural diplomacy in order to maintain 
relationships with the US for defence reasons (Kamrava 2013, 83-103; Kazerouni 2014) and to develop Qatar as a major regional cultural hub (Ouroussoff 2010; Batty 2012). ${ }^{2}$ This policy was also articulated through the establishment of Western-friendly institutions such as $\mathrm{Al}$ Jazeera (established in 1996), the Education Campus of primarily US universities (Virginia Commonwealth University in Qatar opened in 1998) and ultimately the winning of the right to host the FIFA World Cup 2022.

The recent high-profile formation and display of the modern, contemporary and Islamic art collections suggests that collecting is something new in Qatar, a reflection of current royal interest in global cultural practices connected to a desire to participate in universal aesthetic systems as an index of modernity. Using the examples of the first collections created for the Qatar National Museum (opened in 1975), the current Western modern and contemporary art collections (created over the last 15 years) and the Echo Memory collection of found objects (in process since 2012), this paper argues for the situating of collection, curation and display activities within the ongoing process of Qatari national identity construction, preservation and dissemination, as illustrations of the dynamic implementation of the authorized Qatari heritage discourse across multiple sites in Qatar. The discussion addresses the official and unofficial narratives that these collections and collecting practices express through an assessment of the nature of the collections and how and by whom they were and are created, curated and displayed, and presents this as a facet of Qatar's reimagining of itself in the contemporary global age. The discussion considers collecting in Qatar as a traditional local practice that pre-dates the major cultural developments outlined above, as well as being a product of these developments, with both offering a commentary on these larger state-led developments.

\section{Collecting in Qatar}

The limited literature in the English language on collecting in non-Western contexts, the fact that the discipline of museology is a Western construct within which collection studies sits, and the existence of collections created about people rather than by people as a result of colonialism, suggests that the practice of collecting as an indigenous non-Western practice is limited; but there are many examples that indicate otherwise (Erskine-Loftus 2010; Kreps 2003, 2011). The practice of collecting and display at different scales has been in operation in Qatar and other Gulf states since the middle of the twentieth century. A significant example is the private collection of Sheikh Faisal Bin Qassim Al-Thani, an eclectic collection of over 17,000 objects, from cars to radios, religious paraphernalia and numismatics, housed in a purpose-built museum near Doha, Qatar's capital city, which offers a glimpse into the tastes, values and socio-historical conditions of the collector, a member of the ruling family. This collection, created over the last half-century during Qatar's transition to urban wealth and modernity, also reflects an anxiety about rapid change, nostalgia for an idealized pre-oil past, and local cultural systems of knowledge and authority. This nostalgia is typical of many of the older generation of Qatari nationals who have witnessed Qatar's transition from the hardships of the Bedouin lifestyle and a reliance on the unstable pearling economy in the first half of the twentieth century to today's oil- and gas-rich rentier state; there is a pride in the simplicity and self-sufficiency of these earlier lifestyles and their associated values of hard-work, hospitality and consensus rule centred on the tribe and family, which contrasts sharply with the contemporary generation's experience of total dependency on the state for a life of ease and wealth (Ulrichsen 2011; Wright 2011). The older generation fear that traditional values are threatened by Qatar's globalized modernity, and many men of the older generation collect artefacts that represent this earlier period as a means of tangibly retaining and displaying their experience (see Exell 2014 for a detailed discussion of the social conditions within which the Sheikh Faisal collection was created).

Numerous studies have been carried out on collecting practices in the West, both personal and institutional (see for example, Benjamin 1969; Clifford 1994; Pearce 1994, 1995; Akin 1996; MacDonald 2011; Byrne, Clarke, Harrison and Torrence 2011; Harrison, Byrne and Clarke 2013), as well as a studies on contemporary collecting as a performance of Western identity and a practice of twentieth and twenty-first century materialism (for example, Belk et al 1991; Belk 1995; Pearce 1998; Dilworth 2003). These studies contextualized collecting within social, 
cultural and political conditions, be it colonialism and the development of museum collections (Barringer 1997; Bennett 2004; Bhatti 2012; Harrison, Byrne and Clarke 2013; O'Hanlon and Welsch 2000) or consumer culture and its impact on an individual's relationship to material possessions (Belk 1995; Miller 2008). Such a contextual approach, which considers collecting as a manifestation of wider cultural conditions (MacDonald 2011: 92), offers a framework of analysis which can be appropriated to explore the practice of collecting in other parts of the world. For example, Benjamin's observations on the intimate connection of objects to the owner's memories, and collecting as a process of renewal (1969, 60-61), can be directly applied to the private collecting practices of the older generation of Qatari nationals, while Millers' anthropological approach to material possessions, where he argues for the centrality of material culture in people's lives, the study of which can lead us to an understanding of individuals and broader humanity $(2008,1-6)$, offers a method of accessing the contrasting life experiences of, for example, the older generation male Qatari nationals through their personal collections, and the South Asian migrant worker community represented by the Echo Memory collection of found objects, discussed below.

\section{National identity and the other within}

State level rhetoric in the Qatar National Vision 2030 emphasizes the need to '[p]reserve Qatar's national heritage and enhance Arab and Islamic values and identity' (General Secretariat for Development Planning 2008, 12). Qatar's official national heritage narrative focuses on the ruling AI Thani family and their legitimization by the British and Ottoman powers in the region in the late nineteenth and early twentieth century (Fromherz 2012, 17-18). National Day, celebrated on the 18 December since 2007, celebrates the Battle of Wajba in 1892 where, through a collaborative tribal effort lead by Sheikh Jassim bin Mohammed Al Thani, the Turks were defeated, resulting in the maintenance of a degree ofAI Thani independence from Ottoman rule, and, according to the official narrative, the achievement of tribal unity under Sheikh Jassim (Fromherz 2012, 61; Kamrava 2013, 123). Alongside the battle of Wajba as a symbol of unity, Fromherz notes additional reasons why AI Thani came to dominate the equally influential regional tribes, including the stability produced by the long reigns of Jassim, his father Mohammed, and his son Abdallah, a persistent presence in the region of the modern-day capital of Doha and a network of tribal allegiances, together with the support of the British (2012, 62-3). Sites connected to Al Thani are the focus of state heritage investment; for example, Al Zubara, the eighteenth century trading and pearling settlement on the north coast recently excavated by Qatar Museums and Copenhagen University, and inscribed on the World Heritage List in June 2013, and the palace of Sheikh Abd Allah bin Jassim Al Thani (r. 1913-1949), the location of the first Qatar National Museum and the centre of the new National Museum of Qatar. Al Zubara and the museums present a narrative subsuming the role of other tribes and familial tensions within an authorized discourse which presents Al Thani as the natural rulers of the state of Qatar. Today, all state cultural projects are headed by members of AI Thani family, and the collections on display in the two open museums, the Museum of Islamic Art, and Mathaf: Arab Museum of Modern Art, have been created by members of the royal family.

Such uniform narratives are typical of many of the states of the Gulf Cooperation Council (GCC; Bahrain, Kuwait, Oman, Saudi Arabia, UAE and Qatar). Qatar's national identity seeks coherence across a range of local and transnational pressures, including tribal and religious (the membership of the ummah, the global Muslim community, and within this Sunni or Shi'a identities), and must be robust in very particular socio-cultural context. This context has two defining elements: Qatari nationals as a minority in their own country; and an almost unprecedented rapid increase in personal wealth and urban development due to exploitation of the oil and natural gas reserves. Qatari nationals represent around 12 per cent of the population ${ }^{3}$ with the majority of the population consisting of skilled and unskilled expatriate workers with residence status only. Qatar's rapid development has resulted in a pragmatic understanding that international expertise and extensive manpower is essential - the 'outsourcing of the nation state' (Eriksen 2007, 96) - whilst attempting to keep foreign residents at arm's length. Sites of social integration are limited, with newly fabricated public leisure spaces such as shopping malls, the reconstructed Souq Waqif (2006, and ongoing) and Katara Cultural Village 
(opened in 2010 when Doha was the UNESCO Arab Capital of Culture) allowing Qatari, Arab and Western residents to mix, but excluding South Asian construction workers and similar low status foreign males. Parts of Doha, such as the Msheireb area, inhabited until recently by these latter groups, are being reclaimed for Qatari nationals (see below).

Within Qatari society, Qatari identity is conceptualized as one of pure Arab ethnicity (see Cooke 2014, 40-47), tacitly incorporating manumitted slaves of African and other descent (Fromherz 2012, 141-3) and manifest in regionally specific 'National dress', the thobe for men and abaya for women, that signifies belonging to the exclusive, elitist national population (Cooke 2014, 126). Marriage, being born in, or being a long term resident of, Qatar does not automatically bring citizenship, and a distinction is made in local conception between Qatari nationals of pure descent (the first group) and 'Qatari passport holders' - those granted the status for other reasons such as marriage or as elite sports competitors. Qatari national identity and official Qatari citizenship have become synonymous; citizenship comes with extensive privileges, including state subsidies for houses, gifts of land, annual payments, protected positions in the workplace and higher salary scales: this is a citizenship and associated identity that requires protection (see Dresch 2005, 2; Partrick 2012, 47).

The limited representation of even long-term foreign communities, such as Iranians and South Asians, in Qatar's cultural projects, and a national heritage narrative that omits to mention the role of the non-Qatari population in Qatar's development, is antithetical to European and North American policies of cultural representation and inclusion. However, the contemporary socio-cultural context outlined here, where national identity is simultaneously economically and socially privileged, emergent and threatened, goes some way to explaining why Qatari museums and heritage sites, as instruments of the nation building project, do not have a policy of offering such authoritative spaces to non-Qatari communities. Rather, they narrate the authorized state narrative (Al Zubara, the first Qatar National Museum and the new National Museum of Qatar) or are active agents in the dissemination of Qatar's aspiration to be the new cultural centre within the Arab and Islamic world (the Museum of Islamic Art and Mathaf: Arab Museum of Modern Art); Qatar's state cultural policy is an example of 'the conscious mobilization of cultural differences in the service of a larger national or transnational politics' (Appadurai 1996, 13). In terms of national identity construction in this context, as Fibiger and Dougbjerg have observed, '[p]rocesses of exclusion, silencing and selection are not simply outdated operational tools of conventional national practices which we have somehow now left behind' $(2011,144)$ but are ongoing in Qatar's self-realization, where a carefully selected past supports a pure 'Qatari' present and future.

\section{Collecting the nation: from local to global}

How do Qatar's collections and collecting practices, as part of its identity construction, reflect its recent and current socio-cultural context? Lack of documentary records of collections in the Gulf, and a culture of status-related secrecy and privacy (Dresch 2005), where collections might be shown only to privileged visitors, has restricted wider knowledge of the existence of indigenous collections and collecting practices. The Mal Lawal ('From the Old Times') exhibition, which took place in 2012 and again in 2013-14 in Doha, displayed objects from a large number of private collections from Qatar and the region, and the existence of over 50 private museums in the GCC (Hirst 2011), indicates an established interest in the accumulation, ordering and displaying of objects.

The collections of the first Qatar National Museum mirror a trend across the Gulf states at the time, the early 1970s, when national museums were created to help shape new and modern national identities (Fibiger 2011, 188) whilst serving to combat some of the destabilizing effects of a very Gulf-specific modernity. This is a modernity that incorporates aspects of the western modernist discourse, such as a belief in science, technology and the construction of ultramodern cities as launchpads to a transformed future, whilst investing in tradition and the past, all within a benignly autocratic regime (Kamrava 2010, 123-133; see also Fromherz 2012, 158). The first Qatar National Museum opened in the Old Emiri Palace in 1975, shortly after Qatar gained full independence (1971). The building had been constructed in 1901 and 
occupied by the ruler, Sheikh Abd Allah bin Jassim Al Thani, and his sons until 1933. When Sheikh Khalifa bin Hamad Al Thani came to the throne in 1972, one of his first acts was to renovate the Old Emiri Palace and turn it into a national museum. Museums in the western model had not existed in Qatar prior to this date, as, although controlled by British treaties in the nineteenth century and the protectorate since 1916, Qatar was never a fully-fledged colony, with the result that the typical colonial infrastructure was not created; an infrastructure which would usually include the establishment of museums to visualize the country, and educate colonial officers about it (Alivitzatou 2012, 21; Bhatti 2012, 22). Therefore, in order to facilitate the development of the Museum, western consultants and architects were hired, with the construction and content of the Museum led by the British consultant Michael Rice and his consultancy firm, Michael Rice \& Company (Rice 1977).

The new collection for the first Qatar National Museum covered three broad areas: environmental, to present the changing environment, flora and fauna; archaeological, following a desire to establish recognizable time-depth for the new country and its rulers; and ethnographic, to represent and preserve traditional lifeways affected by the rapid modernity oil-wealth had brought (Rice 1977, 82). The archaeological collection was created by the British Archaeologist, Beatrice De Cardi in the late 1960s and early 1970s. According to Mariam Al Mulla (2014), Mustafa Darwish Al Far, the first Director of Qatar National Museum and a participant in the early archaeological work, regarded the pre-historic artefacts as significant for Sheikh Khalifa, 'as they represented his commitment to enhancing the knowledge of Qatari history and identity at a time of great social change'. For the more recent material, a Collections Committee of distinguished Qatari men was established by the Emir, who arranged for a call to be put out by the Ministry of Information for people to bring objects to a collecting centre in Doha, as well as the development of a more formal acquisition process (Rice 1977, 82-3; Al Mulla 2014). According to Al Mulla, the directive was to collect material that represented Qatar, that was 'Qatari'. As the museum was integral to the nation-building process and the legitimation of the Al Thani right to rule, much of the material was drawn from the personal collections of members of the ruling family, such as Mariam Al Attiya, the wife of Sheikh Ali bin Abdullah bin Jassim Al Thani (Al Mulla 2014). The objects collected included tents, vessels and jewellery representing the nomadic Bedouin lifestyle, as well as elaborate furniture representing the more recent settled, urban - and wealthier - lifestyle, and were used to illustrate the rise of Al Thani family from tribal leaders to rulers of a modern state. In an interview with Al Mulla, Mustafa Darwish Al Far also noted that the presentation of everyday objects formed part of the attempt to document and record fast-changing lifestyles. He describes Sheikh Khalifa's aim in establishing a museum as follows: 'He had social and political aims; he aimed to preserve some of old modest objects from Qatari life before the oil invasion' (AI Mulla 2014, 123; see also Rice 1977, 81). The ethnographic material therefore represented two narratives of the new Qatari identity: Al Thani legitimacy - excluding other powerful families, lineages and forms of identity such as the tribe - and the pre-oil past. The travel-writer, Jonathan Raban gives one of the few eye-witness accounts of the first Qatar National Museum in his book, Arabia through the Looking Glass, first published in 1979. He observed the popularity of the museum amongst local Qatari families (1987, 81-2), as well as the immediate authority that the museum displays gave to the objects on show - looking at the displays of costume he writes: 'Their own everyday bangles had been laid out on beds of black velvet and softly backlit'; and of the mannequins dressed the same as the visitors: 'Their authority existed by a trick of the light and a certain stiffness in their posture. Otherwise they were identical' (1987, 82). The museum setting situated the living culture in a past timeframe and homogenized it through the presentation of 'typical' and 'authentic' artefacts that synthesized local culture as heritage (cf. Lionnet 2006, 93-4), whilst the museum context authorized this same version of heritage. Therefore, the shaping of Qatar's heritage was from the first instrumentalized by foreign expertise linked to the technology of the museum which transformed daily practices into a form of heritage for visual consumption. The first Qatar National Museum introduced the public dissemination of the authorized Qatari heritage and identity discourse, and, from local personal recollections ${ }^{4}$ and eyewitness accounts such as Raban's, it seems to have been popular, as a place of sociality, security and nostalgia. 
The first Qatar National Museum closed in 1996 to make way for the construction of the new National Museum of Qatar (NMoQ), due to open in 2018, which will incorporate the original palace building into the spectacular 'desert rose' architectural design created by the Pritzker Prize-winning architect, Jean Nouvel, located almost opposite the Museum of Islamic Art. NMoQ is part of Qatar's identity construction on a global stage, projecting a unified, contemporary, global identity through engagement with international architects and consultants whilst sustaining a coherent narrative of AI Thani rule. This global identity is further developed through the royal family's art acquisitions. As noted above, Qatar has made headlines in the international media for its purchases of Western modern and contemporary art, with the focus on those purchases made by Sheikha Al Mayassa bint Hamad bin Khalifa Al Thani, sister of the Emir, Sheikh Tamim bin Hamad bin Khalifa Al Thani (see Adam 2012; Batty 2012; Forbes 2012; Yaqaab 2012; The Daily Beast/Newsweek 2013). ${ }^{5}$ The ruling family has been collecting on the international market for over a decade: well-known collections include the modern and contemporary Arab art collection of Sheikh Hassan bin Mohammed Al Thani, now the permanent collections of Mathaf: Arab Museum of Modern Art, and the Islamic art collection of the late Sheikh Saud bin Muhammad bin Ali bin Abdullah bin Jassim bin Muhammed Al Thani, displayed in the Museum of Islamic Art (Ouroussoff 2010; The Economist 2012). Sheikh Saud also collected photography items, and a Media Museum was initially planned, and there are state collections of Orientalist art and Natural History (Adam 2008) 6 .

This kind of disciplinary collecting reflects an exposure to the museums and art markets of Europe and the US, and, in comparison to local collecting practices manifest in Sheikh Faisal's museum, the Mal Lawal exhibitions, and the Qatar National Museum's first collections, articulates an engagement with global, or 'universal', value systems, aesthetics and discourses of knowledge (Erskine-Loftus 2013; Exell 2014). Sheikha Al Mayassa's commitment to modern and contemporary art, such as the investment in the works of Damien Hirst and Takeshi Murakami (Ego, 9 February - 24 June 2012, Al Riwaq exhibition space, Doha), leaves many Qatari nationals and foreign observers (as witnessed by discussions in the Twittersphere) equally bewildered as both parties, for different reasons, desire the prioritizing of local heritage in cultural investments, rather than recognizing the state globalization agenda that, according to Sheikha Al Mayassa, links Qatari culture to transnational networks of visual culture, and attempts to create international and intercultural dialogue (Batty 2012; The Economist 2012). A comparison might also be made to seventeenth century royal collecting in England, where foreign art collections were bought wholesale as the embodiment of knowledge and therefore cultural value; taste was purchased as a fast-track method of developing cultural capital (Swann 2001, 16-17; see Bourdieu 1979). In Qatar, cultural capital is a key element of the 'soft power' (Nye 1990; 2004) central to its current political significance.

\section{Another history: The Echo Memory Project (2009-2011)}

The combined processes of globalization and Qatar's rapid development have brought huge numbers of migrant workers to the tiny state. Contemporary transnational migration is a central theme of globalization debates, and Qatar, like other Gulf states, is a major driver of such economic migration: 88 per cent of its population are migrants with residency status only, working in all sectors from construction to higher education, staying for varying periods of time in the country, with some South Asian residents tracing their history in Qatar back a generation or more; as noted above, none will have attained citizenship. These populations are rarely represented in the current or planned museum displays or state-sponsored cultural activities. South Asian communities in particular disappear from heritage narratives the closer these narratives approach the present, as witnessed in the four heritage house museums opened as part of the Msheireb Downtown Doha project in September 2015 (see Figure 1). Msheireb Properties is a subsidiary of the Qatar Foundation for Education, Science and Community Development established in 1995 by the Father Emir Sheikh Hamad, and his wife, Sheikha Moza bint Nasser Al Misned, and is responsible for a number of large-scale cultural developments in Qatar, including the Education City/Hamad Bin Khalifa University complex which hosts the foreign universities in Qatar. The Msheireb redevelopment is transforming an area of the city centre from a dense commercial and domestic zone predominantly inhabited by the South Asian 
communities, into a contemporary mixed-use urban area aimed at attracting Qatari nationals to re-inhabit the centre of their city; it is part of Qatar's nation-building programme. The area has an urban history that can be traced back to the late 1930s, when rapid urbanization followed the discovery of oil in 1939 during the period of the British Protectorate (1916-1971). From the 1960s, migrant workers, predominantly from India, Nepal and Bangladesh, moved in and set up businesses, renting the properties from Qatari landlords who had moved out to the suburbs, until they were re-homed in 2011 in a purpose-built village some distance from downtown Doha (King 2011). This event articulates aspects of the impact of Qatar's nationalizing vision and non-citizens' lack of rights; anecdotal evidence, together with the nature and number of the objects left behind, suggests a resistance to the reality of the enforced move.

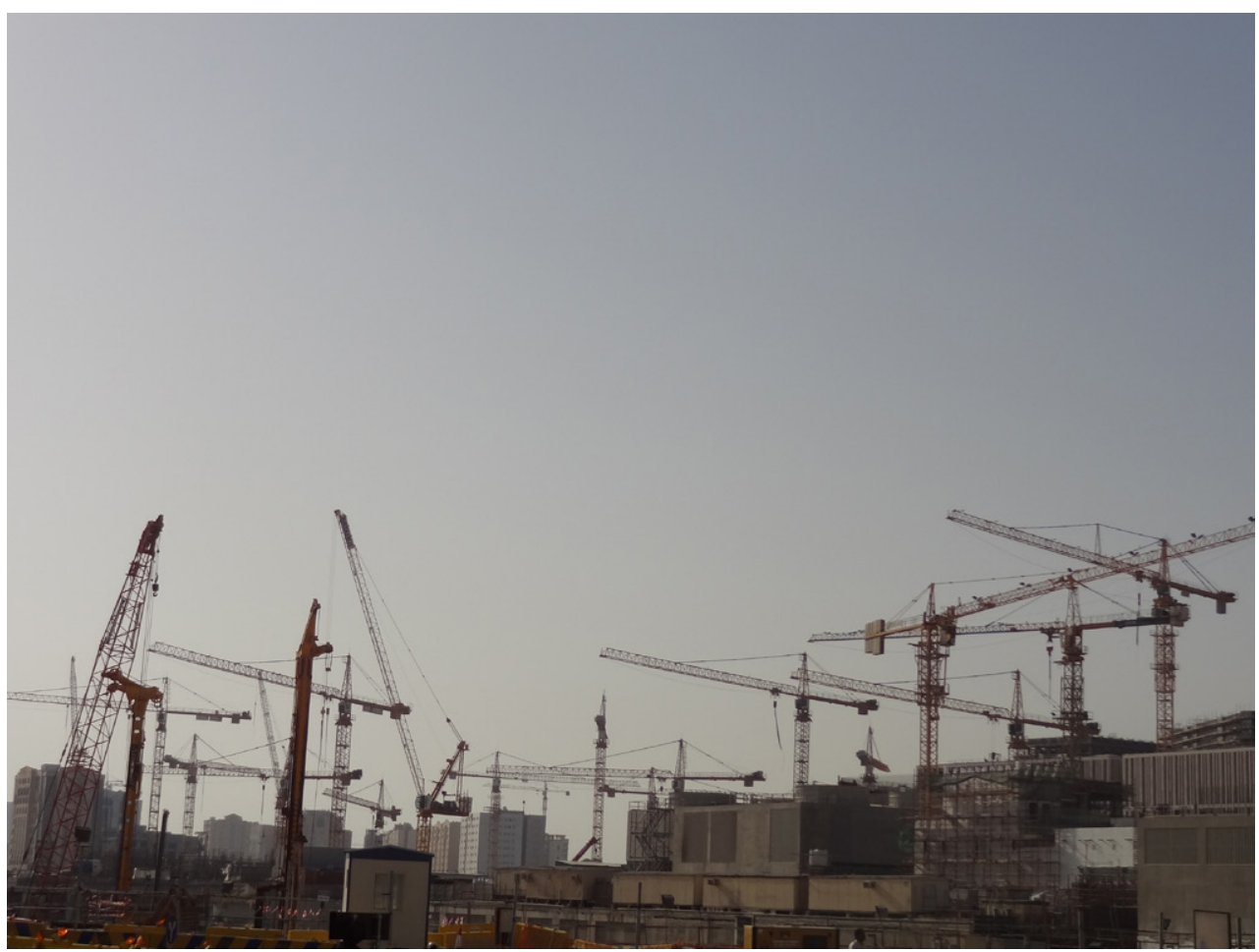

Figure 1: View of the Msheireb development in downtown Doha, May 2013 @ Karen Exell

The Msheireb Arts Center (MAC), located in a 1950s school near the redevelopment, houses the Echo Memory collection of found objects that largely represents the lives of these South Asian communities. The Echo Memory Project (Sada Thakerat al Makan) was initiated in 2009, the concept of Qatari national Issa Al Mohannadi, the then CEO of Msheireb Properties. Al Mohannadi worked on the Project with the Qatari artist Khalifa Al Obaidly, then Assistant Director of Cultural Affairs at Msheireb Properties (now Director of Doha's Fire Station Artist in Residence Program), two London-based artists, Bobby Lloyd and Sally Labern, and the British architect, Tim Makower, at the time Architectural Language Advisor to Msheireb Properties. The object collecting was carried out by Qatari artists, employees at Msheireb Properties and construction workers working on the site's redevelopment, many of whom were from the same countries as the communities represented by the majority of the material collected from the area's upper strata. The collection was gathered in four phases between 2009-2011, following a methodology and typology developed by Lloyd and Labern. The methodology involved numbering each building and attaching the same number to the objects found in that building. 
The focus in the collecting process was on the site of collection, rather than the people who owned and used the objects; for example, an object might be identified by the provenance 'Building 6673'. In the Echo Memory Project, Lloyd and Labern created a typology to structure the collecting, as follows:

- Doors, shutters, screens, gates

- Architectural elements

- Building materials- metal, timber

- Tree trunks

- Signage- shops signs \& street signs, house numbers

- Light fittings

- Chairs, tables, cupboards

- Cookers, fridges etc.

- Electrical items

- Tools

- Nails, screws, cogs etc.

- Coloured glass

- Containers, boxes, packages, suitcases

- Art materials

- Hats, shoes, gloves

- Clothes

- Books

- Stationary

- Posters \& advertising

- Photos

- Toys

- Memory documents- personal collections

- Cars etc.

- Water tanks

- Large objects

Between 3000-4000 objects were gathered (the inventory is still in progress), and these are now stored either at the MAC building that also functions as the largest artefact in the collection or, if large, at a warehouse (Barbour 2012, unpaginated; Fox 2012, 80). Any typology imposes a logic drawn from the value-perspective of those creating it rather than any intrinsic order - or disorder - of the objects themselves. As Hooper-Greenhill observes, taxonomies are socially constructed and create systems of knowledge and hierarchies of value (HooperGreenhill 1992, 4-5; see Foucault 1970, xv; Clifford 1994, 259). The nature of the collection was shaped by the Project's original aim, which was, according to Al Mohannadi, to collect objects that would provide inspiration for Qatari artists to create artworks to be installed within the new Msheireb development, a complete reimagining of the objects. For Al Mohannadi, the objects themselves had no intrinsic value, but were catalysts, vehicles for contemporary artistic expression and an expression of the new Qatari identity. In addition, as the collection - a 
project financed by Msheireb Properties, a state-owned company - formed part of the broader agenda of focussing on Qatari history as part of the official state narrative, the emphasis in the planning was on objects that represented the Qatari past. However, the forty-year gap in Qatari habitation naturally resulted in a collection that was more heavily weighted towards the more recent occupancy by the South Asian communities. The only genuinely 'Qatari' elements were the architectural fragments which reflected an early Qatari architectural aesthetic dating to the period when more affluent settled lifestyles were possible following the discovery of oil in 1939 (Barbour 2012).

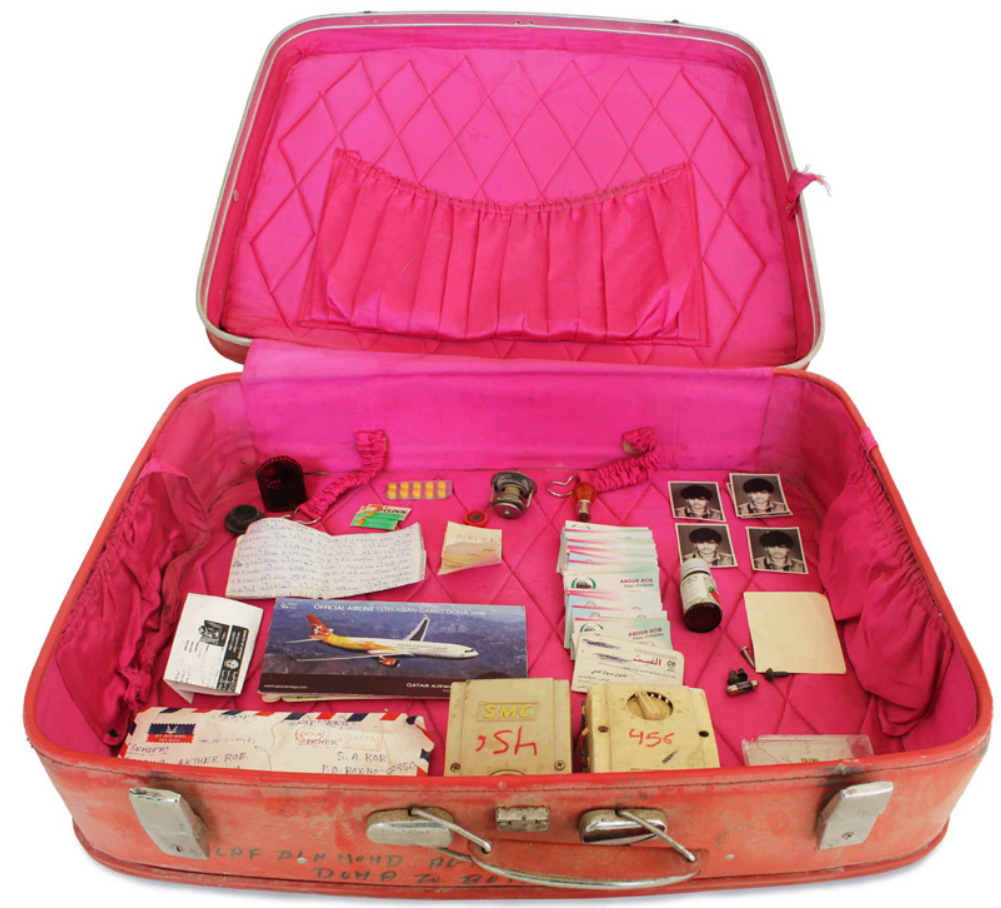

Figure 2: Pink suitcase labelled Doha to Bombay, from Building 456, Msheireb Area (Echo Memory Project) (c) Ben Barbour, Msheireb Arts Center

This inherent emphasis on a South Asian narrative has been increased by the influence of the other individuals involved in, or commenting on, the collection's construction and its use. Ben Barbour, the English artist and curator of the Msheireb Arts Center who joined the Project in 2011, argues that the aim of the Project was 'to record and collect the artefacts, stories and memories of the area as Msheireb undergoes extensive regeneration' (2012, unpaginated; see Fox 2012, 79). Laura Fox, an American commentator then resident in Qatar, observed that the objects were 'neglected items brimming with unwritten local history' (Fox 2012, 80), and both discuss the use of the objects in community workshops involving the South Asian construction workers employed by Msheireb Properties, offering, for example, English language/ art workshops (Fox 2012, 80), an attempt, as Barbour states, to 'redress the balance' between the disenfranchised source community and the reuse of its possessions for a Qatari-only future. ${ }^{7}$ An example of the influence of these value systems shaped by Western post-colonial and subaltern approaches to the past can be found in the displays curated by Barbour for the 'Memories of Msheireb' gallery in Mohammed Bin Jassim House (MBJ House), ${ }^{8}$ one of four heritage house museums that form part of the Msheireb redevelopment. ${ }^{9}$ The role of MBJ House is to narrate the history of the Msheireb area in a sequence of displays that locate the evolution of the area within the wider history of Qatar and its economic development, with an emphasis 
on Qatari habitation and use. MBJ House, along with the other heritage house museums, was designed by Ralph Applebaum Associates (New York), with the content development led by the UK consultancy Barker Langham. The team contributing to the 'Memories of Msheireb' gallery also included Ben Barbour, with his Qatari colleagues from the MAC, Khalifa AI Obaidly and Abdulla Al Naama, and the Msheireb Museums Director, Scott Cooper (in post 2011-mid 2014) and two Qatari colleagues from his office, Nisreen Al Malek and Fahad AI Turky. With such a range of backgrounds, interests and agendas, the gallery went through a number of editions before arriving at a set of designs Barbour considered appropriate. The 'Memories of Msheireb' gallery contains five themed cases, as follows:

1. Early settlement: 1930 s-1950s

2. Events and celebrations

3. Electricity

4. Trade and commerce

5. Healthcare and education

The cases present dense displays of the found objects chosen for their link to the theme but also with an emphasis on their aesthetic appeal, rather than a tight fit to, for example, chronology. Barbour reports that amongst the Qatari nationals there was scepticism of the relevance of displaying everyday objects which contrasted with his own fascination with the revelatory nature of such objects in relation to people's lives (see Rathje and Cullen Murphy 2001; Buchli and Lucas 2001; Buchli 2010). These differing conceptions of value and ideas around what is appropriate to be shown in a museum space, particularly a space connected to the recently constructed authorized Qatari past, is revealing of the contrasting cultural and philosophical frameworks of the different actors on the project, and their interpretation of the project's aims and potential. In the final display designs, Barbour's interest in the social and historical value of the objects is subsumed within his aesthetic impulse as an artist-curator, and the objects are organized and presented with an emphasis on shape, form, texture and colour, so that at first one simply looks at the displays as art. Where Al Mohannadi aimed to produce new work inspired by these objects, Barbour presents the objects themselves, and asks that the viewer consider their ordinary beauty. This museum presentation of the everyday possessions of an excluded community legitimized as art objects may seem superficial, but in a political environment as controlled as Qatar it allows an officially 'invisible' community to be represented without overtly subverting the wider authorized Qatari heritage discourse. Arguably the objects are depoliticized and the politics of heritage transcended, allowing an alternative narrative of Qatari history to exist within the boundaries of the authorized discourse. Of note is the fact that the associated oral histories and documented anecdotes in the gallery are by Qatari nationals: the written and oral history, which presents a purely Qatari past, therefore contrasts with the material culture, which reflects the reality of the area's culturally diverse population.

\section{Conclusions: tradition, identity and modernity in Qatar}

An assessment of collecting practices in Qatar reveals the values and cultural norms of Qatari society, as would such a study in any society; at all levels, collections present a narrative of the collector, regardless of the value of the object collected (Benjamin 1969; Stewart 2007, 136): the extraordinary art market purchases made by AI Thani family over the last decade narrate their extreme wealth and the state's global agenda; the multiple uses of the collection of found objects left by a displaced community that form the Echo Memory Project narrates the project organizer's Western values with their emphasis on object biographies, community representation and aesthetics, resulting in a collection that represents lives otherwise removed 
from the official public record; and the traditional coffee pots and retro radios in private and state national collections narrate a desire to retain disappearing histories in an unstable present.

This discussion has attempted to situate Qatari historical and contemporary collecting practices within the ongoing process of Qatari national identity construction and preservation, and to delineate the multiple agencies at work in the forming of these collections and their display. The introduction of Western heritage philosophies and practices into Qatar to create forms of heritage for public consumption can be traced back to the first Qatar National Museum with the employment of Michael Rice \& Associates to design and populate the Museum, and Beatrice de Cardi to create the national archaeological collection. In the Museum, the collections were ordered according to a linear history constructed as part of the research process, and organized according to Western disciplinary categories of knowledge. Rice notes that the Museum was aimed at Qataris and '[i]ts intention is to provide a basis for the formation of a historical and cultural consciousness' (1977, 82), along a normative Western philosophical and scientific model that ignored the existence of existing local modes of thought (see Kreps 2003, 8; Mejcher-Atassi and Schwartz 2012, 22). Modes of collection and display illustrating local values-systems, philosophies and historical awareness were present prior to the establishment of the Qatar National Museum, in the majlis ${ }^{10}$-collections curated within Qatari homes, exemplified by the Sheikh Faisal Bin Qassim AI Thani Museum, and further illustrated by the large number of private collections displayed in the Mal Lawal exhibitions in Doha in 2012 and 2013-14. Another Western approach to heritage and material culture, this time rooted in the European desire to connect to a tangible past, alongside a post-modern appreciation of the agency and multivalent nature of objects and the existence of multiple narratives, can be found in the approach of the artist-curator, Ben Barbour, to the found objects in the Echo Memory Collection. Barbour states that, "[h]opefully the MAC will create a sense of connection or rootedness to the past, as the area is pushed towards a new future [...] Visitors can make connections between the objects and the immediate area' (Barbour 2012, unpaginated), even if this available past, that of the South Asian communities, is regarded as being of little interest to the intended future residents of the area.

The use of Michael Rice \& Associates to develop the first Qatar National Museum, the current utilization of Western consultancies to design and populate the museums, and Barbour's approach to the Echo Memory Collection, represent an apparent tension in heritage developments in Qatar today, where non-local philosophies underpin methodologies of heritage and identity construction, leaving critics presuming that, as 'there is no heritage in Qatar', Qatar must buy in expertise to construct it (see Fromherz 2012, 4; Exell and Rico 2013). However, an alternative understanding would locate Qatar's heritage industry within its relationship with contemporary globalization and modernity, as a condition of possibility, of agency (cf. Archer 2008, 5), where Qatar actively utilizes Western forms of expertise in order to construct a national identity that is tangible and visible, initially for an internal audience as part of the early national identity project, but increasingly for the outside world. The royal collecting of contemporary art can be seen as part of this process, demonstrating an embrace of global, or 'universal' aesthetics as a demonstration of legitimate taste. As authors who have spent time in Qatar and the region observe (for example, Fromherz 2012, 6-7; Kamrava 2013, 154), the glittering modernity on display - the high-rise buildings, the museums, the vast Americanstyle campus of Education City/Hamad Bin Khalifa University - do not represent the entirety of Qatari culture and society, whose traditional practices and structures continue, if seldom on public display or accessible to outsiders (Dresch 2005, 4; Fromherz 2012, 2-31, Kamrava $2013,110-11)$. Today's spectacle of urban and cultural modernity does not represent a rupture with the past (see Appadurai 1996, 3), but rather Qatar's selective engagement with modernity and its dialectical interaction with global processes. Qatar's collecting processes and modes of display, represented by the traditional majlis, exhibitions such as Damien Hirst's Relics retrospective, and found objects such as the pink suitcase from Bombay in the Echo Memory collection (see Figure 2) represents facets of Qatar's complex contemporary condition. 


\section{Notes}

1 Since writing this article, my monograph Modernity and the Museum in the Arabian Peninsula (Routledge 2016) has been published. This volume develops and expands on many of the discussions here.

2 See also Kluijver, R. (2012) 'Introduction to the Gulf Art World' in The Gulf Art Guide. Available at: http://gulfartguide.com/essay/ [accessed May 2015]

3 Snoj, J. (2013, rev. 2014). Population in Qatar by Nationality. BQ Doha. Retrieved from: http://www.bqdoha.com/2013/12/population-qatar [accessed May 2015]

4 This has emerged from discussions with Qatari students at UCL Qatar over the last three years, who recall being taken regularly to the National Museum as children.

5 See also the article, 'According to an Artprice Study, Qatar will Soon be the Global Leader in the Museum Industry', 1 October 2012, Artprice. http://www.artprice.com/ [accessed May 2015]

6 See also Wise, M. Z. (2007) The Expanding Doha, Travel + Leisure Magazine, July, 4-5. http://www.travelandleisure.com/articles/bridging-the-gulf [accessed May 2015].

7 Ben Barbour was interviewed by Karen Exell, 26 May 2013. This interview informs some of the discussion around Barbour's approach to collecting the Echo Memory objects and curating the cases in Mohammed bin Jassim House.

8 Sheikh Mohammed Bin Jassim (1881-1971) lived in Qatar through the demise of the pearling industry and the discovery of oil, and acted as mayor of Doha for a period.

9 The other museums are Bin Jalmood: The International Slavery Museum, narrating the story of Indian Ocean World slavery and contemporary human trafficking; Company House, which presents the history of Qatar's oil industry; and Radwani house, which presents a preserved traditional house.

10 The majlis is the gendered reception room in a Qatari home, usually a large room attached to the house where the home owner entertains guests and debates issues. Traditional objects were (and sometime still are) displayed in the majlis. See Exell 2014 for more detail on the role of the majlis in demonstrations of knowledge and authority in Qatar and the Gulf.

\section{References}

(2012) 'The World's 100 Most Powerful Women - No. 100, Sheikha Mayassa Al-Thani', August, Forbes Magazine.

(2012) 'Qatar's Culture Queen', 31 March, The Economist.

(2013) 'Is Sheikha Mayassa the Art World's Most Powerful Woman?' The Daily Beast/ Newsweek.

Adam, G. (2008) 'Fireworks as Qatar Steals the Show', 29 November, Financial Times.

(2012) 'Energy - and Ambition to Match', 9 March, Financial Times.

Akin, M. (1996) 'Passionate Possession: The Formation of Private Collections', in W. David Kingery (ed.) Learning from Things: Essays on Material Culture Studies, 102-28, Washington, DC: Smithsonian Institution Press. 
Alivizatou, M. (2012) Intangible Heritage and the Museum: New Perspectives on Cultural Preservation, Walnut Creek, CA.: Left Coast Press.

Al Mulla, M. (2014) 'The Development of the First Qatar National Museum', in Karen Exell and Trinidad Rico (eds) Cultural Heritage in the Arabian Peninsula: Debates, Discourses and Practices, 117-25, Burlington VT and Farnham, Surrey: Ashgate Publishing.

Appadurai, A. (1996) Modernity at Large: Cultural Dimensions of Globalization, Minneapolis, USA: University of Minnesota Press.

Archer, K., Bosman, M.M., Amen, M.M. and Schmidt, E. (2008) 'Locating Globalisations and Cultures', in Kevin Archer, Martin M. Bosman, Mark M. Amen and Ella Schmidt (eds) Cultures of Globalisation: Coherence, Hybridity, Contestation, 1-14, Oxford and New York: Routledge.

Batty, D. (2012) 'The Rise of the Gulf Art Scene', 16 April. The Guardian, UK.

Belk, R.W. (1991) 'Possessions and the Sense of the Past' in Russell W. Belk (ed), Highways and Buyways: Naturalistic Research from the Consumer Behavior Odyssey, 114-30, Provo, UT: Association for Consumer Research.

Belk, R.W. (1995) Collecting in a Consumer Society, London: Routledge.

Barbour B. (2012) Salvaging Memory: The Msheireb Arts Centre (MAC) and the Echo Memory Project. Unpublished Essay.

Barringer, T. and Flynn, T. (1997) Colonialism and the Object: Empire, Material Culture and the Museum, London: Routledge.

Benjamin, W. (1969) 'Unpacking my Library - An Essay about Collecting', in Hannah Arendt (ed) Illuminations: Essays and Reflections, 59-67, New York: Schocken Books.

Bennett, T. (2004) Past Beyond Memory: Evolution, Museums and Colonialism, London: Routledge.

Bhatti, S. (2012) Translating Museums: A Counterhistory of South Asian Museums, Walnut Creek, CA: Left Coast Press.

Bourdieu, P. (1979) Distinction: A Social Critique of the Judgement of Taste, Cambridge, MA: Harvard University Press.

Buchli, V. (2010) 'Archaeology of the Recent Past: A Reflection on Knowledge Production' in Andrea Luka Zimmerman and Lasse Johannson (eds) Estate: Art Politcs and Social Housing in Britain, 105-16, London: Myrdle Court Press.

Buchli, V. and Lucas, G. (2001) 'The Archaeology of Alienation: A Late Twentieth Century British Council House' in Victor Buchli (ed) The Archaeology of the Contemporary Past, 158-67, London: Routledge.

Byrne, S., Clarke, A., Harrison, R. and Torrence, R. (2011) 'Networks, Agents and Objects: Frameworks for Unpacking Museum Collections', in Sarah Byrne, Anne Clarke, Rodney Harrison and Robin Torrence (eds) Unpacking the Collection: Networks of Material and Social Agency in the Museum, 3-28, New York: Springer. 
Clifford, J. (1994) 'Collecting Ourselves' in Susan Pearce (ed) Interpreting Objects and Collections, 258-68, London: Routledge.

Crinson, M. (2001) 'Nation-Building, Collecting and the Politics of Display' Journal of the History of Collections 13, 231-50.

Cooke, M. (2014) Tribal Modern: Branding New Nations in the Arab Gulf, Berkeley LA London: University of California Press.

Dilworth, L. (2003) Acts of Possession: Collecting in America, Brunswick, NJ: Rutgers University Press.

Dresch, P. and Piscatori, J. (2005) Monarchies and Nations: Globalisation and Identity in the Arab States of the Gulf, London and New York: I.B. Tauris.

Eriksen, T. (2007) Globalization: The Key Concepts, Oxford: Berg.

Erskine-Loftus P. (2010) 'A Brief Look at the History of Museums in the Region and Wider Middle East', Art \& Architecture, special edition: Museums in the Middle East 13, 18-20.

Erskine-Loftus P. (2013) 'Introduction: Common Purpose and Uncommon Outcomes: The Cultural Transferability of Museums' in Pamela Erskine-Loftus (ed) Reimagining Museums: Practice in the Arabian Peninsula, 10-65, Edinburgh and Boston: MuseumsEtc.

Exell, K. (2014) 'Collecting an Alternative World: The Sheikh Faisal Museum in Qatar' in Karen Exell and Trinidad Rico (eds) Cultural Heritage in the Arabian Peninsula: Debates, Discourses and Practices, 51-70, Burlington, VT. and Farnham, Surrey: Ashgate Publishing.

Exell, K. 2016 (in press). 'Locating Qatar on the World Stage: Museums, Foreign Expertise and the Construction of Qatar's Contemporary Identity' in Pamela Erskine-Loftus, Mariam Al Mulla and Victoria Hightower (eds) Representing the Nation: Heritage, Museums, National Narratives, and Identity in the Arab Gulf States, London and New York: Routledge.

Exell, K. and Rico, T. (2013) "There is No Heritage in Qatar": Orientalism, Colonialism and Other Problematic Histories', World Archaeology 45 (4): 670-85. Available at: http://dx.doi.or $\mathrm{g} / 10.1080 / 00438243.2013 .852069$

Fibiger, T. B. (2011) 'Global Display_Local Dismay. Debating "Globalized Heritage” in Bahrain', History and Anthropology 22, 187-202.

Fibiger, T. B. and Daugbjerg, M. (2011) 'Introduction: Heritage Gone Global. Investigating the Production and Problematics of Globalized Pasts', History and Anthropology 22, 135-47.

Foucault, M. (1970) The Order of Things, London: Tavistock.

Fox, L. (2012) 'Grass Roots Spaces and Imaginings in Doha', Harpers Bazaar Art (Summer), 78-83.

Fromherz, A.J. (2012) Qatar: A Modern History, New York and London: I.B. Tauris.

General Secretariat for Development Planning (2008) Qatar National Vision 2030, Doha: GSDP. 
Harrison, R., Byrne, S. and Clarke, A. (eds) (2013) Reassembling the Collection: Ethnographic Museums and Indigenous Agency, Santa Fe: School for Advanced Research Press.

Hirst, A. (2011) Museums in the GCC: Development for Whom? Unpublished Masters Dissertation, Durham University

Hooper-Greenhill, E. (1992) Museums and the Shaping of Knowledge, London and New York: Routledge.

Hopper, P. (2007) Understanding Cultural Globalisation, Cambridge and Malden, MA: Polity Press.

Kamrava, M. (2013) Qatar: Small State, Big Politics, Ithaca and London: Cornell University Press.

Kazerouni, A. (2014). 'Mirrors of the New Order: Museums in the Arab Principalities of the Persian Gulf between 1991 and 2011.' 19th Dar al-Athar al-Islamiyyah Cultural Season. Al Maidan Cultural Centre, Kuwait City: Unpublished Lecture, January.

Khalil, R.F. and Shaaban, K. (2012) 'Rebuilding Old Downtowns: The Case of Doha, Qatar', in Manfred Schrenk, Vasiliy V. Popovich, Peter Zeile and Pietro Elisei (eds) Proceedings REAL CORP 2012 Tagungsband, 677-89

King, K.A. (2011) The Heart of Doha? The Narrative of Qatari National Identity offered by the Msheireb Urban Development Project. Unpublished MPhil Dissertation, Department of Sociology, Trinity College Dublin.

Kreps, C. F. (2003) Liberating Culture: Cross-Cultural Perspectives on Museums, Curation and Heritage Preservation, London: Routledge.

Kreps, C.F. (2011) 'Non-Western Models of Museums and Curation in Cross-Cultural Perspective', in Sharon MacDonald (ed.) A Companion to Museum Studies, Second Edition, 457-76, Oxford: Blackwell.

Lionnet, F. (2006) 'The Mirror and the Tomb: Africa, Museums and Memory', in Bettina M. Carbonell (ed) Museum Studies: An Anthology of Contexts, Fourth Edition, 92-103, Malden MA, Oxford, UK, Victoria, Australia: Blackwell Publishing.

MacDonald, Sharon (2011) 'Collecting Practices' in Sharon MacDonald (ed) A Companion to Museum Studies, 81-97, Oxford: Wiley-Blackwell.

Mejcher-Atassi, S. and Schwartz, J.P. (eds) (2012) 'Introduction: Challenges and Directions in an Emerging Field of Research' in Sonja Mejcher-Atassi and John-Pedro Schwartz, Archives, Museums and Collecting Practices in the Modern Arab World, 1-30, Farnham; Burlington VT: Ashgate Publishing.

Miller, D. (2008) The Comfort of Things, Cambridge: Polity.

Nye, J. (1990) Bound to Lead: The Changing nature of American Power, New York: Basic Books.

Nye, J. (2004) Soft Power: The Means to Success in World Politics, New York: Public Affairs. 
O'Hanlon, M. and Welsch, R.L. (eds) (2000) Hunting the Gatherers: Ethnographic Collectors, Agents and Agency in Melanesia, 1870s-1930s, Oxford: Berghan.

Ouroussoff, N. (2010) 'Building Museums and a Fresh Arab Identity', 26 November, New York Times.

Partrick, N. (2012) 'Nationalism in the Gulf States', in David Held and Kristian Ulrichsen (eds), The Transformation of the Gulf: Politics, Economics and the Global Order, 47-65, London and New York: Routledge.

Pearce, S. (1994) Interpreting Objects and Collections, London: Routledge.

Pearce, S. (1995) On Collecting: An Investigation into the European Tradition, London:

Routledge.

Pearce, S. (1998) Collecting in Contemporary Practice, London, Walnut Creek CA., New Delhi: Sage; AltaMira Press.

Raban, J. (1987) Arabia through the Looking Glass, London: Pan Books Ltd.

Rathje, W. and Murphy, C. (2001) Rubbish! The Archaeology of Garbage, Tucson, AZ: University of Arizona Press

Rice, M. (1977) 'The National Museum of Qatar’ Museum International 29: 78-87.

Scharfenort, N. (2014) 'The Msheireb Project: A Sustainable Approach to New Arab Urban Design?', in Karen Exell and Trinidad Rico (eds) Cultural Heritage in the Arabian Peninsula: Debates, Discourses and Practices, 189-204. Burlington VT and Farnham, Surrey: Ashgate Publishing.

Stewart, S. (2007) On Longing: Narratives of the Miniature, the Gigantic, the Souvenir, the Collection, Durham, NC: Duke University Press.

Swann, M. (2001) Curiosities and Texts: The Culture of Collecting in Early Modern England, Philadelphia: University of Pennslyvania Press.

Ulrichsen, K. C. (2011) Insecure Gulf: The End of Certainty and the Transition to the PostOil Era, London: Hurst and Company.

Wright, S. (2011) 'Qatar', in Christopher Davidson (ed) Power and Politics in the Persian Gulf Monarchies, 113-33, London: Hurst and Company.

Yaqaab, T. (2012) 'Can Billion-dollar Investments put Qatar on the Cultural Map?', 20 October, The Independent.

${ }^{*}$ Dr Karen Exell

Lecturer, Museum Studies/Coordinator, MA Museum and Gallery Practice

UCL Qatar,

Doha

Office: +97444578698

Mobile: +9746605 1704

Email: k.exell@ucl.ac.uk

www.ucl.ac.uk/qatar 